Article Type: Research Paper

\title{
Tax Revenue Diversification in Indonesia
}

\author{
Jefrio Martiyus ${ }^{1 *}$
}

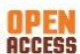

\section{AFFILIATION:}

${ }^{1}$ Magister of Applied Economics, Faculty of Economic and Business, Universitas Padjadjaran, West Java, Indonesia

\section{*CORRESPONDENCE:}

jefrio18001@mail.unpad.ac.id

THIS ARTICLE IS AVALILABLE IN:

http://journal.umy.ac.id/index.php/esp

DOI: 10.18196/jesp.v22i1.7523

\section{CITATION:}

Martiyus, J. (2021). Tax Revenue Diversification in Indonesia. Jurnal Ekonomi \& Studi Pembangunan, 22(1), 48-58.

\section{ARTICLE HISTORY}

Received:

18 Nov 2019

Revised:

25 Aug 2020

09 Sep 2020

Accepted:

13 Dec 2020
Abstract: State finances are a vital issue that is still being debated among scholars. This paper focuses on revenue diversification issues affecting the variables in this study, discussed by Deborah A Carrol in the USA. Some researchers believe that revenue diversification is an alternative path to stabilize state accounts in a crisis. Furthermore, diversification can also capture policy reactions to political and economic constraints. Using panel data analysis, it was found that four significant variables affected the tax revenue diversification, including average monthly salaries, per capita expenditure, homeownership, and the Gini Ratio. This study uncovered that Indonesia's tax revenue sources were not diverse, with more than 47 percent coming from income taxes. In theory, this condition should get more attention from the government because the more diverse the revenue, the more stable the government account becomes. Keywords: Revenue Diversification; Tax Structure; $\mathrm{HHI}$ Index JEL Classification: H2O, H71, R51

\section{Introduction}

The financial situation in central and local government has been a notable issue among researchers, economists, and government administrators worldwide. These issues have become necessary since the Great Depression in 1970 and the economic downfall in 1980. The economic downturn is not easy, particularly for the regional budget due to budget balance specifications. The Great Depression affected state revenue, which caused the budget crisis. Since the crisis arose, many taxpayers failed to fulfill their obligation to pay taxes. This situation creates more burden on the government's budget as taxes are the biggest revenue sources for the government's income.

In response to past fiscal crises, public managers believe that diversity in revenue structure is one source for state revenue. There is one procedure to stabilize the revenue during fluctuated economic cases, which is revenue diversification. This diversification is similar to investment portfolios. It can reduce the revenue's fluctuation, which is correlated with single-source revenue. Countries with more diversified revenue systems are proposed to be more resistant than countries with less diversified revenue systems.

Many scholars have studied the structure of local government revenue and fiscal decision-making in previous research. The revenue diversification problem has received more attention in regional and 


\section{Martiyus \\ Tax Revenue Diversification in Indonesia}

central government since the 1960s and 1970s due to response to fiscal crises in large cities and the tax rebellion (Ulbrich, 1991; Zorn, 1991). Further, Joyce and Mullins (1991) saw that all of those problems stem from the civilian's negative perception that the government has been grown out of the box from what they want.

As a result of these crises, central and regional governments should find another way to support public services. Thus, revenue diversification potentially becomes an essential device for central and regional governments to maintain their steps and prepare themselves for economic crises and fiscal pressure.

Ulbrich (1991) studied the advantages of revenue diversification. He argued that there are three advantages of diversified revenue. First, it promotes equity by capturing revenues from individuals who can evade some taxes but not others. Second, it stimulates efficiency by reducing the distortion of economic decisions that are overly reliant on one revenue source. Third, it maintains a lower tax rate. Other studies that agree with Ulbrich (1991) and follow his study are Park and Park (2018); Chernick, Langley, and Reschovsky (2011); and Yan (2008).

Contrary to Ulbrich (1991); Ladd and Weist (1987) disagreed with the statement above that the balance revenue system is not sufficient, efficient, and equitable. They suggested that the tax system may not be more diversified but reflects the importance of policy goals. Moreover, Kilby (2014) explained that diversification's positive effect should be equidistant with fiscal policies. Sarkar (2016) examined revenue diversification in banks and found that increasing income diversification would increase institutional risk, resulting in increased inefficiency.

Dye (1966) saw the effect of revenue diversification through socioeconomic variables. He said that socioeconomic variables influenced local revenue. Bingham (1978) found that the number of revenue types is the most potent single variable that influences tax concentration. Jung (2002) also agreed with both arguments. He studied economic activity and concluded that economic activity is a substantial factor in deciding the state revenue structure.

In the political view, Nice (1987) concluded that many political parties would create more progressive revenue structures. These arguments align with Pajari's (2008) study in Georgia, which found that the probability of adopting Local Optimal Sales Taxes (LOST) had a positive association with property value, income, and taxable sales. Heyndels and Vuchelen (1998) conducted a tax rate analysis in 589 cities in Belgium. They found that property tax and income tax rates between close neighbors were the same as reduced intensity according to geographical distance.

In Indonesia, income diversification research is still limited. Most of the studies focus on revenue diversification in financial institutions (banks) and non-profit institutions, while there is still no discussion of revenue diversification in government finances. Researches on taxes as a source of state income in Indonesia mostly focuse on one type tax, as was done by Mardiana and Prawoto (2016) and Yudisyus (2013) who examined the factors 
that influence the amount of advertisement tax revenue. Setiyono, Maramis, and Setianto (2019) examined the effect of diversification of bank income and its relation to bank stability in banks listed on the Financial Service Authority and the Indonesia Stock Exchange from 2008-2017. They uncovered that diversification would strengthen bank stability.

Following Setiyono et al. (2019), Zulfikar and Pangestuti (2018), Madyan, Wahyuningati, and Firdausi (2018), Santiyano and Suk (2017), and Sariartha and Husnan (2015) also have the same conclusion. The diversification of the bank's income showed a good effect on reducing the risk on the bank's revenue streams. Furthermore, Sariartha and Husnan (2015) also did not find a significant difference between small banks and large banks' efficiency due to income diversification.

In brief summary, this study tried to analyze Indonesia's economic strength through its income diversification as a basis for developing economic policies to face global financial volatility. This is due to the fact that despite being one of the top 20 countries with the highest GDP globally, it does not necessarily put Indonesia in a safe position during the global financial shock. This study intends to introduce the concept of income diversification as a means to support Indonesia's readiness amidst world economic fluctuation. This study investigated the value of income diversification practice in Indonesia for financial stability and explored the main factors in formulating proper and efficient fiscal policy. Since this subject is rarely discussed by the economic scholar in Indonesia, the concept of income diversification is the novelty offered by this study to enrich the study on state financial stability

According to previous studies, many variables affect revenue diversification. This study adopted some variables explained by Carroll (2005), who classified them into three main variables (economic, political, and demographical), with each variable represented by some derivative indicators.

This paper aims to see the effect of economic, demographic, and political variables on Indonesia's tax revenue diversification. The data were collected from Statistics IndonesiaBadan Pusat Statistik (BPS) from 2015-2019. Then, it used two stages of time-series crosssectional panel data regression to estimate the dependent variable. This paper is divided into several chapters: methodology, empirical results, a discussion, and a conclusion.

\section{Research Method}

In this study, the data were collected from the thirty-four provinces in Indonesia from 2015-2019. Then, it employed two-stage time-series cross-sectional regression to estimates revenue diversification. In the first stage, the diversification was measured based on HHI Index (Misiolek \& Elder, 1988; Turnbull, 1998; Wagner, 1976). This study utilized the method of integrating the seven tax revenue categories in Indonesia. Then, the concentration ratio was also measured for the big four tax sources (CR4). Thus, tax revenue diversification was calculated as the following: 


$$
R D=\frac{1-\sum_{i=1}^{5} R_{i}^{2}}{0.8}
$$

where, $\mathrm{Ri}$ is the fraction of tax revenue. This measure implies that the higher RD values, the higher diversification levels among tax structures.

Then, in the second stage, the numerous factors influencing this revenue diversification were measured using eight independent variables representing three leading indicators (economic, political, and demographic). The $\mathrm{HHI}$ index obtained was from the first stage and acted as the dependent variable.

The second stage to determine the numerous factors influencing the level of state tax revenue diversification was following by Carroll (2005):

$$
H H I_{i t}=\propto+E_{i t} \beta_{1}+P_{i t} \beta_{2}+D_{i t} \beta_{3}+C_{i t} \beta_{4}+\varepsilon_{i t}
$$

where, $\mathrm{E}$ is matrices of economic, $\mathrm{P}$ is for political, $\mathrm{D}$ is for demographic, respectively. The dependent variable was tax revenue diversification, as measured by the HHI Index. The economy's matrices were represented by two main variables: average monthly salaries and per capita expenditure. Three variables represented the political matrices: civil rights rate, political rights rate, and democratic institution rights. The demographical matrices were reflected by three variables: homeownership, poverty rate, and the Gini Ratio. All data were collected from the BPS's publication. The description of variables is presented in Table 1.

\begin{tabular}{|c|c|}
\hline Variables & Description and Data Sources \\
\hline & Economic Variables \\
\hline $\begin{array}{l}\text { Log Average Monthly } \\
\text { Salaries (X1) } \\
\text { Log Per Capita } \\
\text { Expenditure (X2) }\end{array}$ & $\begin{array}{l}\text { Average of net wage per month of employee and labor constant } \\
\text { rupiah. } \\
\text { Per capita general expenditures for every province in the year } 2017 \\
\text { constant rupiah. } \\
\quad \text { Political Variables }\end{array}$ \\
\hline $\begin{array}{l}\text { Civil Right Rate (X3) } \\
\text { Political Right Rate (X4) } \\
\text { Democratic Institution } \\
\text { Right (X5) }\end{array}$ & $\begin{array}{l}\text { The annual civil rights rate in Indonesia in the year } 2017 \\
\text { Annual political right rate by BPS in the year } 2017 \\
\text { Annual rights of the democratic institution by BPS in the year } 2017\end{array}$ \\
\hline Homeownership (X6) & The percentage of households who have their own home \\
\hline $\begin{array}{l}\text { Population Poverty Rate } \\
\text { (X7) }\end{array}$ & $\begin{array}{l}\text { The percentage of people in poverty using data of SUSENAS in the } \\
\text { first semester of } 2017\end{array}$ \\
\hline Gini Ratio (X8) & $\begin{array}{l}\text { Gini Ratio coefficient to see the distribution of income in Indonesia } \\
\text { in the year } 2017\end{array}$ \\
\hline
\end{tabular}

Table 1 Description of Variables

Source: Statistics Indonesia-Badan Pusat Statistik (BPS).

It is commonly believed that economic variables play an essential role in improving the level of revenue diversification. Thus, this variable is likely to be positively correlated with revenue diversification. Needless to say, coefficient $\beta_{-} 1>0$. Then, the two following 
variables (political and demographical) seem to have a positive correlation with dependent variables. This argument is based on Carroll's (2005) finding that both variables positively affected revenue diversification. Thus, coefficients of $\beta \_2$ and $\beta \_3>0$.

\section{Result and Discussion}

Table 2 provides the descriptive statistics for each dependent and independent variable included in the model. Based on the theory, the HHI index's magnitude indicates the concentration level, whether monopoly or diverse. Based on Table 2, it could be concluded that the average $\mathrm{HHI}$ index value was 37.85 percent, meaning that Indonesia's revenue diversification was relatively small. It indicated that the revenue source only concentrated on one or two types of tax.

Table 2 Summary Statistics of Equation Variables

\begin{tabular}{lcccc}
\hline \multicolumn{1}{c}{ Variable } & Mean & Std. Dev. & Min & Max \\
\hline Revenue Diversification (HHI Index) & 3785,33 & 105,55 & 3672,74 & 3945,11 \\
Average Monthly Salaries (Log Rp.) & 3,41 & 0,11 & 3,17 & 3,67 \\
Per Capita Expenditure (Log Rp.) & 4,01 & 0,09 & 3,81 & 4,27 \\
Civil Right Rate (\%) & 82,69 & 10,51 & 51,01 & 100,00 \\
Political Right Rate (\%) & 67,02 & 9,75 & 38,05 & 86,52 \\
Democratic Institution Right (\%) & 71,60 & 10,57 & 47,25 & 93,98 \\
Homeownership (\%) & 79,52 & 8,63 & 47,12 & 97,99 \\
Population Poverty Rate (\%) & 11,19 & 5,93 & 3,47 & 28,54 \\
Gini Ratio & 0,36 & 0,04 & 0,27 & 0,44 \\
Observation & 170 & 170 & 170 & 170 \\
\hline
\end{tabular}

Source: Data processed.

Table 3 illustrates the Concentration Ratio (CR4) index of revenue source in Indonesia budgeting since 2015-2019. It shows the CR4 value has always been more than 96 percent and indicated the increasing trend. In 2015, the CR4 value was about 96 percent and increased 2 points to 98.20 percent in 2019. This finding depicted that Indonesia's tax revenue source was not diverse; most of them came from income tax.

Moreover, the value of the $\mathrm{HHI}$ index presented a high result. The trend of increasing the $\mathrm{HHI}$ index every year also followed the upward trend in CR4. Based on the HHI value, which was more than 2500 , it could be denoted that most taxes in Indonesia were not well diversified. One source of state revenue was still monopolized by one tax source.

To select a suitable model based on the panel data's characteristics, the Hausman and the Likelihood ratio tests were conducted. These tests specified that the fixed effects model was appropriate. The results of panel data regression processing using STATA revealed that this study's most suitable model was the fixed effect model. 
Martiyus

Tax Revenue Diversification in Indonesia

Table 3 Source of Tax, CR4 Index, and HHI Index of Indonesia 2015-2019

\begin{tabular}{|c|c|c|c|c|c|}
\hline Source & 2015 & 2016 & 2017 & 2018 & 2019 \\
\hline Income tax & 48.56 & 51.14 & 47.48 & 49.16 & 50.07 \\
\hline Value-added tax & 34.16 & 32.08 & 35.78 & 36.47 & 36.69 \\
\hline Property Tax & 2.36 & 1.51 & 1.25 & 1.13 & 1.07 \\
\hline Custom Tax & 11.66 & 11.17 & 11.41 & 10.04 & 9.26 \\
\hline Others Tax & 0.45 & 1.34 & 1.17 & 0.49 & 0.48 \\
\hline Import Tax & 2.52 & 2.53 & 2.61 & 2.43 & 2.18 \\
\hline Export Tax & 0.30 & 0.23 & 0.31 & 0.29 & 0.25 \\
\hline CR4 & 96.89 & 96.92 & 97.28 & 98.10 & 98.20 \\
\hline $\mathrm{HHI}$ & $3,672.74$ & $3,779.90$ & $3,674.27$ & $3,854.65$ & $3,945.11$ \\
\hline
\end{tabular}

Source: Statistics Indonesia-Badan Pusat Statistik (BPS).

Table 4 represents the output of the empirical estimation. Column (1) reports the regression-based fixed effect without robustness standard error, while column (2) reports robustness. Both columns show a consistent result based on the value of significance and coefficient. Based on the output from Table 4, from eight independent variables, at five percent error, only four variables were significant in the model: the average monthly salaries, per capita expenditure, homeownership, and the Gini Ratio.

Empirically, the average monthly salaries had a negative effect on the $\mathrm{HHI}$ value. Increasing one point of wage would decrease the HHI value by 461 points. It contrasts with Carroll (2005) and the size of Indonesia's CR4, which is dominated by income tax. The assumption is that the greater a person's income will increase the amount of income tax so that the HHI value will be even greater. This phenomenon might occur because the variable of monthly salaries only captured taxpayers who came from the formal sector. Workers who worked in the non-formal sector were likely not to be covered by tax revenue, so even though workers' average wage was higher, it did not significantly affect the addition of income tax.

Yan (2008) has answered this phenomenon based on his study on Georgia State in 19862004. He found that personal income had a negative correlation with revenue instability. Increasing income means increasing tax, and it reduces the effect of revenue risk in the Georgia Government. Furthermore, Kilby (2014) also uncovered a similar result. States with a higher income tax in the USA tended to be stable than others.

Furthermore, variable per capita expenditure showed a positive effect on the $\mathrm{HHI}$ index. Increasing one point of this variable would increase 6,870 points of $\mathrm{HHI}$ value. This evidence can be accepted because per capita expenditure has been measured based on monthly consumption. Most of these consumable goods have been subject to valueadded tax. This finding is contrary to the empirical result by Carroll (2005) that found that per capita expenditure had a negative effect on revenue diversification. However, this result is parallel with the study on revenue complexity theory articulated by Wagner (1976) and supported by Baker (1983). Furthermore, Park and Park (2018) also found that the economic perspective represented by per capita expenditure might be applicable for revenue diversification and public spending. 
The political variable revealed an insignificant result. The rate of political, civil, and democratic institution rights that represented political variables were not significant on $1 \%, 5 \%$, and $10 \%$, respectively. This finding indicated that political structure could not be measured for fiscal choice (Park \& Park, 2018). Deno and Mehay (1987) found that the government's focus was not on the political structure but other factors, such as median income. Also, homeownership positively correlated with $\mathrm{HHI}$ value. Increasing one point of homeownership would increase 12 points of $\mathrm{HHI}$. The growth of homeownership would increase the value of property tax, and CR4 value would also increase. This finding is also supported by Carroll's (2005) findings that homeownership positively correlated with revenue diversification. The intuition is that the increase of homeownership means increasing property tax and directly increasing the $\mathrm{HHI}$ Index.

The next variable of demographical indicators is the poverty rate. According to empirical results in this study and similar to Carroll (2005), this variable was not significant. However, the Gini Ratio was added as a new variable to represent demographical indicators to clarify poverty's effect on revenue diversification. Gini Ratio gives information on the wage gap between poor and rich. This measure seems more powerful than the poverty rate because it can measure the income tax gap between two types of wage.

Table 4 Estimation Results (Fixed Effect Regression)

\begin{tabular}{lcc}
\hline \multicolumn{1}{c}{ Variables } & $(1)$ & $(2)$ \\
\hline Average Monthly Salaries & $-461.3756^{* * *}$ & $-461.3756^{* * *}$ \\
Per Capita Expenditure & $(159.6551)$ & $(164.7525)$ \\
& $6807.88^{* * *}$ & $6807.88^{* * *}$ \\
Civil Right Rate & $(666.464)$ & $(495.8792)$ \\
& -0.2345831 & -0.2345831 \\
Political Right Rate & $(0.8945321)$ & $(0.8146465)$ \\
& 0.4301026 & 0.4301026 \\
Democratic Institution Right & $(0.9600856)$ & $(0.8727354)$ \\
& -0.0659418 & -0.0659418 \\
Homeownership & $(0.7320567)$ & $(0.7150539)$ \\
& $12.68249 * *$ & $12.68249 *$ \\
Population Poverty Rate & $(4.048889)$ & $(7.232175)$ \\
& 2.26552 & 2.26552 \\
Gini Ratio & $(12.7434)$ & $(9.123201)$ \\
& $-768.4668 * *$ & $-768.4668 * *$ \\
Constant & $(449.0866)$ & $(377.1306)$ \\
N Observation & $-22671.55^{* * *}$ & $-22671.55^{* * *}$ \\
N province & $(2586.222)$ & $(2084.033)$ \\
Robust SE & 170 & 170 \\
R-Square & 34 & 34 \\
\hline
\end{tabular}

Note: The dependent variable is revenue diversification ( $\mathrm{HHI}$ Index). All standard errors are reported in parentheses.

* Significant at $10 \%, * *$ Significant at $5 \%, * * *$ Significant at $1 \%$

Source: Data processed. 


\section{Martiyus}

Tax Revenue Diversification in Indonesia

This study has found generally that the Gini Ratio was also significant in the model. This relationship was negative. Increasing one point of the Gini ratio would decrease 768 points of HHI value. This evidence showed that the increasing Gini Ratio caused more gaps in income inequality. This fact widens the gap income among higher and lower-income wages. Eventually, income tax sources are limited to those on high income because the lower-income lost their revenue source. This loss can be related to previous findings that they moved to the informal sector that could not be covered in this study.

This investigation's results disclosed that the value of $R$ square was 0.7548 . It signified that the independent variables could predict the dependent variable for 75.48 percent, and the rest was by others.

The evidence in this study exposed that only two of three indicators of revenue diversification had a significant effect. Meanwhile, the political indicator represented by tree variables was not significant in the model. The most significant variable affecting revenue diversification was economic variables. This finding also aligns with studies from Park and Park (2018) and Yan (2008).

\section{Conclusion}

Revenue diversification is needed to maintain state finances' stability to faces the recession or fiscal crises and increase public expenditure. In Indonesia, this study's focus is still limited. Most research only focuses on revenue diversification in non-profit institutions, banks, and income structures in the regional community. However, this research has thrown up many questions in need of further investigation. Further work needs to be done to establish whether variables are fit with the Indonesian condition.

Average monthly salaries should show a positive relationship with HHI value. However, this study revealed vice versa. Increasing salaries would increase the nominal income tax. Further research is needed to examine and include the average wage variable by considering informal paid workers' wages.

Political variables were not significant in this study. It showed that the political climate in Indonesia was inconsistent with the state revenue structure. The Indonesian Government should concern about this problem because it relates to the stabilization of revenue diversification state budgeting.

The demographic variable was represented by three variables. However, only two of them were significant in the model. The insignificance of the poverty population rate was because this rate was not powerful to determine diversification revenue. The poverty rate only captures the percentages of poor people without seeing their contribution to financial state budgeting. Meanwhile, homeownership and Gini Ratio could directly catch society's role in the source of income tax. 
This result's finding clearly revealed that economic variables strongly influenced revenue diversification. Demographical variables were significant, but it seemed not too strong to explain their relationship.

Nevertheless, this research also has limitations. First, the researchers only measured revenue diversification by using the $\mathrm{HHI}$ Index, which actually can be measured through a variety of ways: tax and non-tax-revenue diversification categories used by Suyderhoud (1994) and Carroll (2009) and seven different categories of the government form by Nelson and Svara (2012).

Furthermore, there are still many variables that might affect the level of revenue diversification in Indonesia. However, data limitations prevented the researchers from adding these variables. In future studies, it is possible to include various variables recommended by some experts concerned in this study based on Indonesian conditions.

\section{References}

Baker, S. H. (1983). The determinants of median voter tax liability: An empirical test of the fiscal illusion hypothesis. Public Finance Quarterly, 11(1), 95-108. https://doi.org/10.1177/109114218301100106

Bingham, R. D. (1978). Innovation, bureaucracy, and public policy: A study of innovation adoption by local government. The Western Political Quarterly, 31(2), 178-205. https://doi.org/10.2307/447811

Carroll, D. A. (2005). Are state governments prepared for fiscal crises? A look at revenue diversification during the 1990S. Public Finance Review, 33(5), 603-633. https://doi.org/10.1177/1091142105276440

Carroll, D. A. (2009). Diversifying municipal government revenue structures: Fiscal illusion or instability? Public Budgeting and Finance, 29(1), 27-48. https://doi.org/10.1111/j.1540-5850.2009.00922.x

Chernick, H., Langley, A., \& Reschovsky, A. (2011). Revenue diversi cation in large US. IMFG Papers on Municipal Finance and Governance.

Deno, K. T., \& Mehay, S. L. (1987). Municipal management structure and fiscal performance: Do city managers make a difference? Southern Economic Journal, 53(3), 627. https://doi.org/10.2307/1058759

Dye, T. R. (1966). Politics, economics, and the public: Policy outcomes in the American States. Rand Mcnally \& Company.

Heyndels, B., \& Vuchelen, J. (1998). Tax mimicking among Belgian municipalities. National Tax Journal, 51(1), 89-100. https://doi.org/10.1086/ntj41789314

Joyce, P. G., \& Mullins, D. R. (1991). The changing fiscal structure of the state and local public sector: The impact of tax and expenditure limitations. Public Administration Review, 51(3), 240-253. https://doi.org/10.2307/976948

Jung, C. (2002). The impact of the special purpose local option sales tax (SPLOST) on local government finance in Georgia. Retrieved from https://www.semanticscholar.org/paper/The-impact-of-the-Special-Purpose-LocalOption-Tax-Jung/c20f70041822172374dd2db8a002302b09793cfa2\#paper-header

Kilby, N. (2014). Does tax revenue diversification help states weather economic downturns? Evidence from the great recession. MPA/MPP Capstone Projects, 12. Retrieved from https://uknowledge.uky.edu/mpampp_etds/12 
Ladd, H. F., Weist, D. (1987). State and local tax systems: Balance among taxes vs. balance among policy goals. In Stocker, F. D. (Ed.), The quest for balance in state-local revenue structures (pp. 39-69). Cambridge, MA: Lincoln Land Institute. Retrieved from http://scholar.google.com/scholar_lookup?hl=en\&publication_year=1987\&pages=3 $\underline{9-}$

69\&author $=$ H. + F. + Ladd\&author $=$ D. + Weist\&title $=$ The + quest + for + balance + in + sta te-local + revenue + structures

Madyan, M., Wahyuningati, A., \& Firdausi, N. A. (2018). Faktor penentu risiko saham perbankan di Indonesia (Studi pada industri perbankan yang terdaftar di Bursa Efek Indonesia). Ekonomi Bisnis, 23(2), 43-49. https://doi.org/10.17977/Um042v23i2p43$\underline{49}$

Mardiana, L., \& Prawoto, N. (2016). Analisis penerimaan pajak reklame Kabupaten Magelang dengan pendekatan VECM periode 2010 - 2014. Jurnal Ekonomi \& Studi Pembangunan, 17(2), 193-202. https://doi.org/10.18196/jesp.17.2.3984

Misiolek, W. S., \& Elder, H. W. (1988). Tax structure and the size of government: An empirical analysis of the fiscal illusion and fiscal stress arguments. Public Choice, 57(3), 233-245. https://doi.org/10.1007/BF00124807

Nelson, K. L., \& Svara, J. H. (2012). Form of government still matters: Fostering innovation in U.S. municipal governments. American Review of Public Administration, 42(3), 257-281. https://doi.org/10.1177/0275074011399898

Pajari, R. (2008). Georgia's local option sales tax: Who adopts it and why? Southeastern Political Review, 12, 127-153. https://doi.org/10.1111/j.1747-1346.1984.tb00007.x

Park, J. H., \& Park, S. (2018). The effect of revenue diversification and form of government on public spending. Journal of Public Budgeting, Accounting and Financial Management, 30(2), 211-229. https://doi.org/10.1108/jpbafm-02-2018-0012

Santiyano, B. J., \& Suk, K. S. (2017). Penghindaran risiko, diversifikasi pendapatan dan efisiensi intermediasi bank di Indonesia. Joumal of Business \& Applied Management, 10(1), 1-10. https://doi.org/10.30813/jbam.v10i1.865

Sariartha, A., \& Husnan, S. (2015). Pengaruh diversifikasi pendapatan terhadap kinerja bank. Jurnal Siasat Bisnis, 19(1), 27-35. https://doi.org/10.20885/isb.vol19.iss1.art3

Sarkar, S. (2016). The dynamics of revenue diversification and efficiency of banks In India. IIM Kozhikode Society \& Management Review, 5(2), 156-172. https://doi.org/10.1177/2277975216644807

Setiyono, A., Maramis, M. M., \& Setianto, R. H. (2019). Peran diversifikasi pendapatan pada pengaruh kekuatan pasar terhadap stabilitas bank. Al Tijarah, 5(1), 38-45. Retrieved from https://ejournal.unida.gontor.ac.id/index.php/altijarah/article/view/3612

Statistics Indonesia. Badan Pusat Statistik (BPS). Retrieved from https://www.bps.go.id/

Suyderhoud, J. P. (1994). State-local revenue diversification, balance, and fiscal performance. Public Finance Quarterly, 22(2), 168-194. https://doi.org/10.1177/109114219402200202

Turnbull, G. K. (1998). The overspending and flypaper effects of fiscal illusion: Theory and empirical evidence. Journal of Urban Economics, 44(1), 1-26. https://doi.org/10.1006/juec.1997.2056

Ulbrich, H. H. (1991). Nonproperty taxes. In local government finance John E. Petersen and Dennis R. Strachota (Ed.)). Government finance officers association.

Wagner, R. E. (1976). Revenue structure, fiscal illusion, and budgetary choice. Public Choice, 25(1), 45-61. https://doi.org/10.1007/bf01726330 


\section{Martiyus}

Tax Revenue Diversification in Indonesia

Yan, W. (2008). The impact of revenue diversification and economic base on revenue stability : An empirical analysis of county and state governments. Doctoral Dissertations. University Of Kentucky. https://uknowledge.uky.edu/gradschool diss/619

Yudisyus, O. (2013). Penerimaan pajak reklame dan faktor-faktor yang mempengaruhinya. Jurnal Ekonomi \& Studi Pembangunan, 14(2), 137-143. Retrieved from https://journal.umy.ac.id/index.php/esp/article/view/1261

Zorn, C. K. (1991). User charges and fees in local government finance. (In John E. Petersen \& Dennis R.Strachota (Ed.)). Chicago: Government Finance Officers Association.

Zulfikar, F. I., \& Pangestuti, I.R.D. (2018). Diversifikasi pendapatan, risiko kredit, loan to deposit ratio, risk aversion dan net interest margin. Diponegoro Journal of Management, 7(4), 277-286. Retrieved from https://ejournal3.undip.ac.id/index.php/djom/article/view/22377 